\title{
From Circular Economy to Circular Ecology: A Review on the Solution of Environmental Problems through Circular Waste Management Approaches
}

\author{
Luca Adami (D) and Marco Schiavon *(D) \\ Department of Civil, Environmental and Mechanical Engineering, University of Trento, Via Mesiano, 77, \\ I-38123 Trento, Italy; luca.adami@unitn.it \\ * Correspondence: marco.schiavon@unitn.it; Tel.: +39-0461-282605
}

check for

updates

Citation: Adami, L.; Schiavon, M. From Circular Economy to Circular Ecology: A Review on the Solution of Environmental Problems through Circular Waste Management Approaches. Sustainability 2021, 13, 925. https://doi.org/10.3390/su13020925

Received: 30 November 2020

Accepted: 9 January 2021

Published: 18 January 2021

Publisher's Note: MDPI stays neutral with regard to jurisdictional claims in published maps and institutional affiliations.

Copyright: (c) 2021 by the authors. Licensee MDPI, Basel, Switzerland. This article is an open access article distributed under the terms and conditions of the Creative Commons Attribution (CC BY) license (https:// creativecommons.org/licenses/by/ $4.0 /)$.

\begin{abstract}
Background: The application of concepts linked to the circular economy (CE) has led to a sudden development of studies in numerous fields. However, the level of environmental sustainability of CE strategies could be improved and this topic deserves more attention by the scientific community. This research addresses this gap and aims at presenting a new concept, named circular ecology $\left(\mathrm{CE}_{\mathrm{L}}\right)$, and its application to the field of waste management. (2) Methods: The paper presents a literature review on the criticalities of $\mathrm{CE}$ and on examples of studies that implement the $\mathrm{CE}_{\mathrm{L}}$ principles. (3) Results: The review highlights that $\mathrm{CE}_{\mathrm{L}}$ principles are widely applied to several fields of waste management, showing promising opportunities to export the results to other geographical contexts. (4) Conclusions: If supported by governments, $\mathrm{CE}_{\mathrm{L}}$ approaches may allow solving multiple environmental problems at once, with clear economic, time, resources, and emission savings.
\end{abstract}

Keywords: environmental sustainability; recycling; recovery; reuse; anaerobic digestion; biochar; biofuels; case studies; organic waste

\section{Introduction}

The concept of circular economy (CE) has attracted the interest of researchers in several fields in the last decade (from economists to engineers, environmental scientists and sociologists), as proved by the increased number of papers available in the Scopus database containing the word "circular economy" in the title, abstract, or keywords. The number of publications has grown from 121 in 2010 to 2460 in 2020 [1]. The increasing number of works has produced a large variety of definitions and shades of the concept of CE over the years [2,3].

The concept of CE dates back to 1966 [4] and circularity approaches in economy were later analyzed in 1991 by Leontief [5]. However, the most recent version of CE was formalized in 2013 [6] in four key aspects: CE (1) replaces the "end-of-life" concept with the "restoration" concept; (2) it pursues the use of renewable sources of energy; (3) it refuses the use of toxic compounds; and (4) it aims at reducing waste through rearranging production and supply processes. The concept of CE was further deepened by the resolution adopted by the United Nations on 25 September 2015, known as "Agenda 2030" [7], and by the definition of the 17 Sustainable Development Goals [8,9].

As reported in Birat [10], CE must be seen as an integrated approach that goes beyond the logic of profit, requiring political motivations towards sustainable consumption paradigms. The development of a CE is thus linked to local environmental legislation, the availability of incentives and capital, and the awareness of the population, which may determine significant differences among different countries [11].

As reported by Cheng et al. [12], one of the advantages of CE is its capability of breaking the bond between environmental vulnerability and economic poverty. The bene- 
fits related to the implementation of CE strategies are usually more evident in countries subjected to rapid industrialization and poor environmental regulations, causing environmental damages and pollution [13].

In 2008, with the introduction of the Waste Framework Directive [14], the European legislation made an explicit connection between CE and waste management (WM). The evident and direct relationship between CE and WM was further highlighted by Merli et al. [15] in 2018. Aguilar-Hernandez et al. [16] highlight the potentially beneficial role of $\mathrm{CE}$ as an approach to reduce circularity gaps in waste recovery and recycling. As the authors state, Europe and North America produce annually 1.6-2.2 $t$ of waste per capita that could be further recycled/recovered. In addition to CE, the concept of bio-economy deserves to be mentioned. In this case, the concept of replacement prevails with respect to that of circularity, i.e., bio-economies are based on the replacement of fossil resources with biogenic ones [17]. If bio-based CE is not mentioned as such, most European countries address it in their strategies. Bio-waste management appears to be the main driver in the transition towards CE [18]. CE has many potential drivers favoring the application of its base principles: (1) several technologies are available for an efficient use of resources, both in the production and remanufacturing stages; (2) governments have improved their environmental legislations in the last decades, including regulations on WM; and (3) public awareness is increasing, and so is the power of people to orient the market to more sustainable products. However, market issues, the lack of investments in more advanced technologies, and the legislative process of governments are slowing down the transition towards the solution of environmental issues through CE initiatives [19].

Although the indirect benefits deriving from resource efficiency strategies have a positive influence on the environment, the publications on CE have largely focused on supply-chain optimization [20-22], leaving the environment on a second level. In a recent work, Millar et al. [23] stressed the importance of considering environmental protection as a key aspect of CE principles. In a recent publication, Horvath et al. [24] highlight the need for considering ecological benefits/limitations when assessing CE approaches. The authors propose to integrate one of the major indicators used in the European Union ("circular material use", CMU) with the comparison between the "ecological footprint" and the "bio-capacity" of a system. This would allow accounting for the ecological pressures that the mere use of the CMU indicator would not be able to consider. Additional metrics have been implemented in recent years [25] to assess the environmental sustainability of CE strategies. However, if on one side several assessment tools are available, on the other side the principles that move the thinking and implementation of CE strategies often put environmental sustainability on a secondary level with respect to economic sustainability. There are, of course, some exceptions, like WM, for instance. The issue is then a matter of environmental principles rather than the availability of environmental assessment tools.

The relationship between economic growth and environmental sustainability was discussed by several authors in the last decade. Kallis [26] promoted the concept of sustainable degrowth, i.e., a sustainable reduction of the throughput of the society. According to the author, the implementation of this vision would unavoidably bring environmental benefits. A debate has started in the last decade on the dualism between economic degrowth and steady-state economy. According to some authors, this dualism is only apparent, since economic degrowth should be intended as a set of measures leading to a globally fair steady-state economy [27]. According to Kiser [28], however, the economic growth clearly contradicts the concept of resource efficiency in the supply chain, because the aim of selling more materials and the use of less resources form a paradox. According to Skene [29], finally, circles can never deliver growth, unless circles are intended as spirals. The author affirms that economic growth necessarily creates environmental deterioration.

As highlighted in a recent work [30], pollution prevention and control measures can lead to unavoidable negative impacts on the economy in the short term. One of the main challenges of $C E$ is to overcome this conflict. The present paper has two aims: (1) the introduction a new concept, concerning CE approaches that stress the need for environmental 
protection and restoration, where circularity is intended in terms of material reuse (waste in particular) and the mutual solving of more environmental problems; and (2) providing an overview on case studies that already implement this concept. Regarding the first aim, a new concept, which can be named "circular ecology" $\left(\mathrm{CE}_{\mathrm{L}}\right)$, may be developed to fill this gap and allow circular strategies to combine economic progress with environmental advances, thus leading to win-win opportunities. In other words, $\mathrm{CE}_{\mathrm{L}}$ may be intended as a reinforcing concept of $\mathrm{CE}$ that pursues a more evident balance between economic and environmental performance. In addition, $\mathrm{CE}_{\mathrm{L}}$ may refer to cases where the solution to one environmental problem can be the occasion to solve another environmental problem. When shifting to $\mathrm{CE}_{\mathrm{L}}$, the cultural barriers undermining the full application of $\mathrm{CE}$ strategies may play a less important role in the implementation of actions that involve circularity in solving environmental issues. This may be due to the fact that the contribution of consumers' habits would be less crucial in $\mathrm{CE}_{\mathrm{L}}$ than in $\mathrm{CE}$. Consumers would only be involved in the market of recycled waste deriving from environmental restoration approaches. Regarding the second aim, case studies selected from the recent literature will be presented and discussed to highlight the opportunities deriving from the implementation of the above presented principle of $\mathrm{CE}_{\mathrm{L}}$ (i.e., circular strategies that overcome the main barriers of $\mathrm{CE}$, including the lack of attention to environmental issues).

\section{Materials and Methods}

\subsection{Generalities on the Review Method}

To carry out the here presented review, the Preferred Reporting Items for Systematic Reviews and Meta-Analyses (PRISMA) was adopted (Figure 1) [31]. The analysis started from a total number of 219 publications, selected on the basis of their affinity with the theme of $\mathrm{CE}$, environmental remediation and WM.

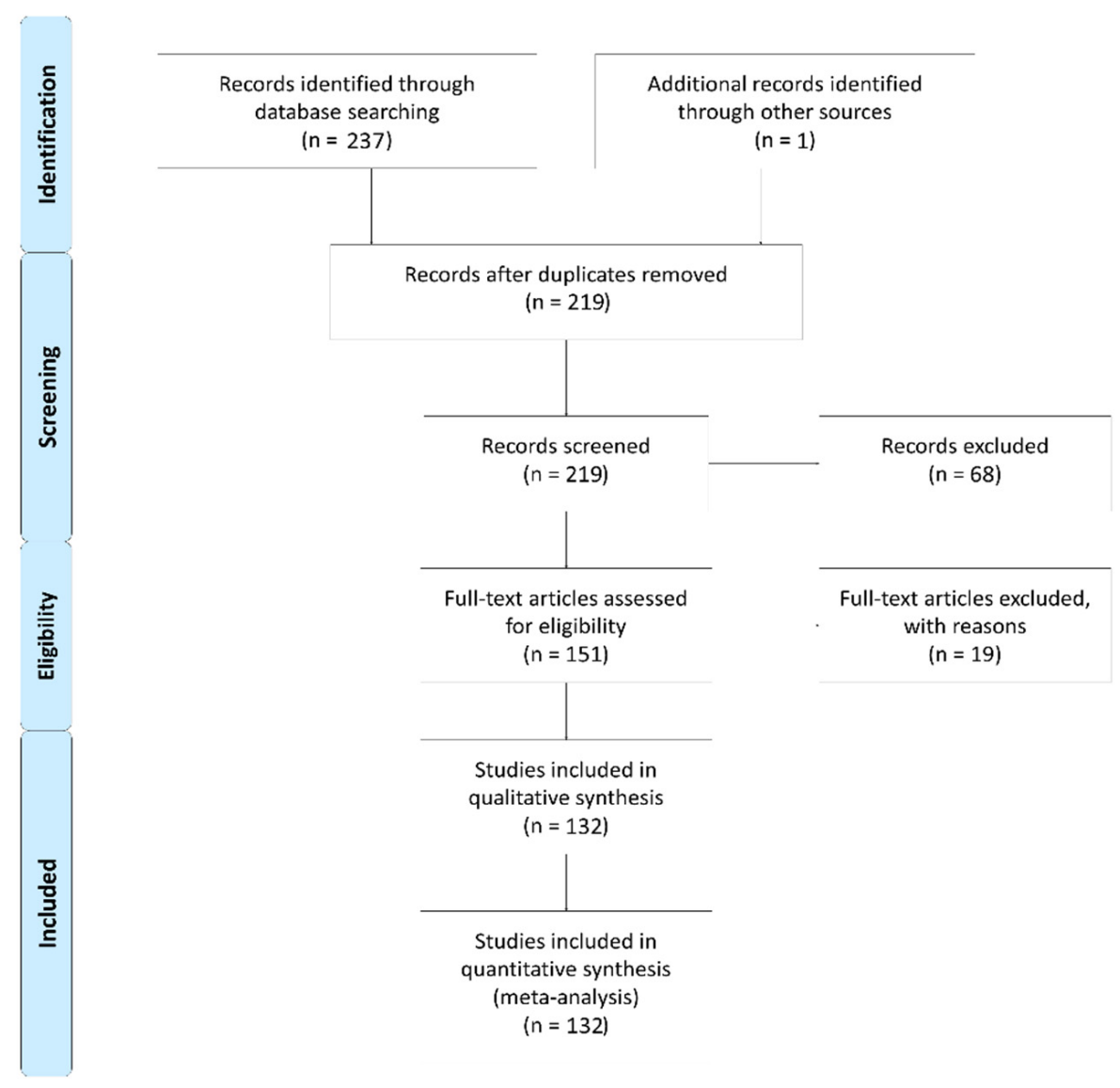

Figure 1. Results on the PRISMA analysis. 


\subsection{Data Sources and Search Strategies}

The 219 publications were selected by consulting the Scopus database [1]. After a first selection, 68 papers were excluded from the review as not relevant to the topic of the present paper. The reading and screening allowed us to discard 19 further irrelevant papers from the collection of 151 papers selected for eligibility. The remaining 132 papers are cited in this review because of their relevance to the general topic of $\mathrm{CE}$, because they perform critical analyses of $\mathrm{CE}$ and because they present novel methodologies or case studies on the topic of $\mathrm{CE}_{\mathrm{L}}$. The research considered only peer-reviewed papers written in English and only studies with full text available. Figure 1 reports the results of the PRISMA analysis.

\subsection{Selection Strategy}

The paper eligibility for inclusion in this study was assessed first of all on the basis of the relevance of the title to the criteria reported in Section 2.2 and, as a second check, on the basis of the relevance of the abstract. Both the authors performed the evaluation of the papers. The papers that passed the checks were organized in categories according to the topic discussed: generalities on $\mathrm{CE}$, industrial ecology, generalities on $\mathrm{CE}_{\mathrm{L}}$ and examples/case studies on $\mathrm{CE}_{\mathrm{L}}$.

\subsection{Characteristics of the Selected Publications}

The selected publications were organized alphabetically, divided into the above mentioned categories and a score between 1 and 5 was attributed to each paper according to both the level of relevance to the topics of the categories and the level of novelty in the field. Figures 2 and 3 present the distribution of the selected papers according to the category they belong to and the journal title, respectively. The temporal distribution of the publications cited is presented in Figure 4.

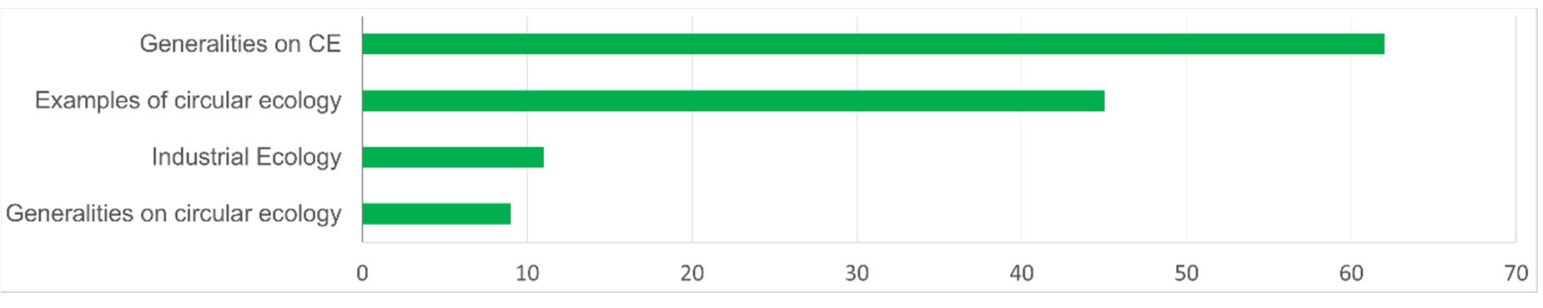

Figure 2. Distribution of the selected papers according to the category they belong to.

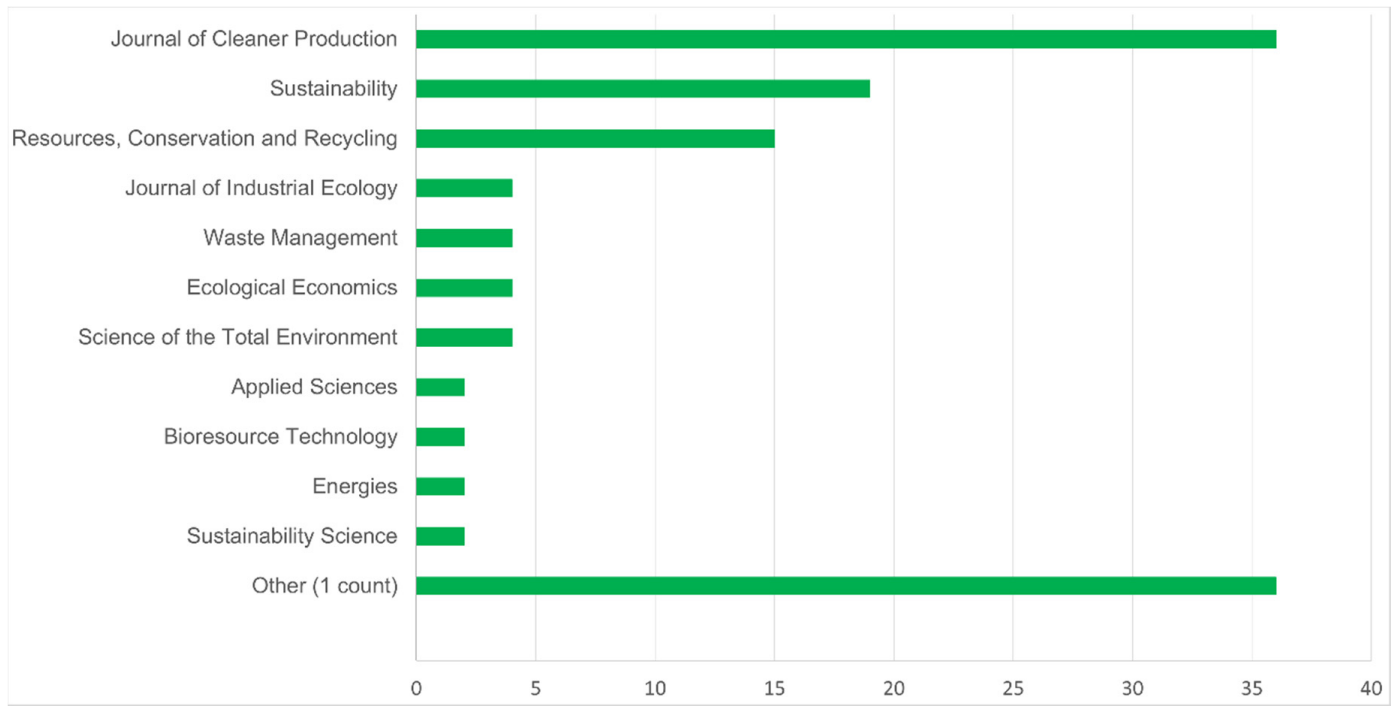

Figure 3. Distribution of the selected papers according to the title of the source. 


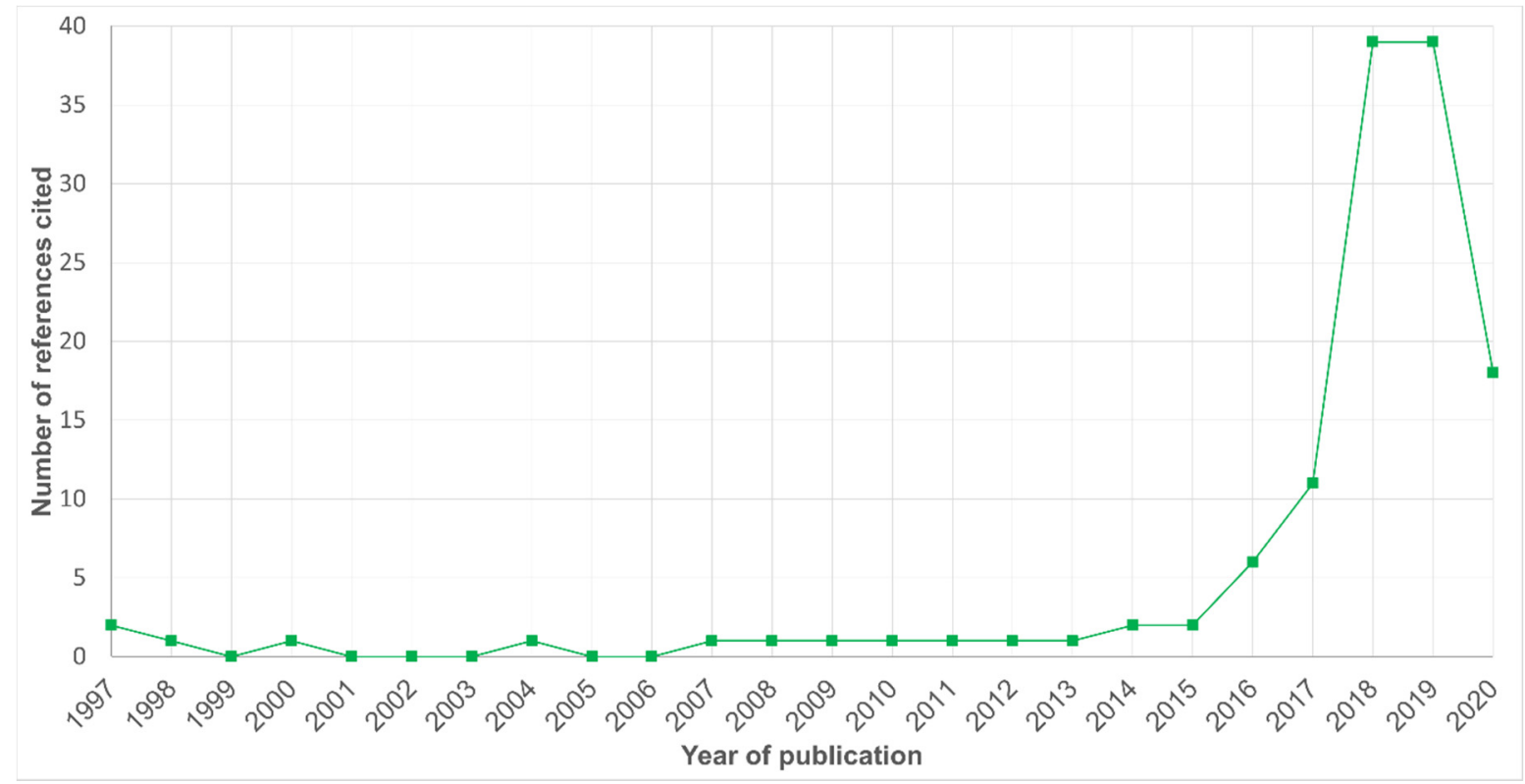

Figure 4. Distribution of the selected papers according to year of publication.

\section{Critical Review of CE Approaches}

\section{1. $C E$ and $W M$}

In addition to product manufacturing and supply chains, in the last decade $\mathrm{CE}$ approaches have been implemented in a wide range of fields, including the construction sector [32], plastic materials [33], tourism [34,35], urban management [36-38], agro-food industry [39,40], and WM [41,42]. WM is a key aspect of the four main components of CE [43]: (1) the recirculation of resources and energy, the minimization of resources demand, and the recovery of value from waste; (2) a multi-level approach; (3) its importance as a path to achieve sustainable development; and (4) its close relationship with the way society innovates. Pires and Martinho [44] proposed a waste hierarchy index to measure the waste hierarchy within a CE context. The authors applied the index to municipal solid waste, considering recycling and reuse as positive contributors to $\mathrm{CE}$, and incineration and landfilling as negative contributors. However, waste-to-energy processes (including incineration) still play a fundamental role in an integrated WM vision aimed at minimizing the impacts on the environment [45]. The concept of Life Cycle Thinking (LCT) was introduced to assess the impacts of WM by considering the whole supply chain, from raw material extraction and conversion, manufacture and distribution, use and/or consumption, to treatment and disposal [46]. A key factor is to avoid burden shifting, among geographical regions, unit processes, or impact categories/sustainability pillars.

According to Tisserant [47], the tracing of domestically generated waste might be relevant for policy makers, because it would allow them to estimate the losses of secondary resources and related environmental impacts. The trade of waste also plays an important role in redistributing secondary resources across the world.

According to Reh [48], energy and material efficiencies in both production and recycling processes are the recipe for a sustainable future. Moreover, the ongoing development will allow recycling a large number of valuable components with increasing quantity for high quality re-use. However, Stahel [49] argues that recycling has a limited ability to keep materials in circulation. According to Ranta et al. [50], it is important that policymakers find ways to facilitate value creation through the principles of "reduce" and "reuse" for the $\mathrm{CE}$ to reach its full potential.

Construction and demolition (C\&D) WM comprises one of the largest waste stream globally. Aslam et al. [51] proposed a review of C\&D WM in China and USA. They show that EU, USA and China produce nearly $38 \%\left(3.8 \times 10^{9}\right.$ ton/year $)$ of the total amount 
of $C \& D$ waste globally produced $\left(10^{10}\right.$ ton/year). They state that the lack of market mechanisms to favor recovery, unclear financial conditions and the fragmented nature of the construction industry represent the most significant challenges in the development of the field. On the opposite, Gálvez-Martos et al. [52] presented a synthesis of core principles and best practice related to $C \& D$ waste sector in Europe, highlighting that this sector is well and broadly established, even if the nature and availability of the final secondary materials and market penetration differ widely across countries. López Ruiz et al. [53] reviewed the framework of C\&D waste sector, describing five lifecycle stages for the adoption of the CE concept in the C\&D WM: (i) preconstruction; (ii) construction and renovation; (iii) collection and distribution; (iv) end-of-life; and (v) material recovery and production.

The management of organic waste is another important topic of CE. According to Ubando et al. [54], waste biomass has driven the boundaries of biorefineries in circular bio-economy, adding value to secondary products. Wainaina et al. [55] describes the current generation state of organic solid waste and different disposal technologies, particularly for composting and $\mathrm{AD}$. The authors elaborate on the details of their treatment process and their environmental, social and economic applicability. Both technologies are not completely economically feasible. For this reason, they have not been successfully applied in many countries and the public economic support of the initiatives is still a common practice. Xue et al. [56] present an inventory analysis and impact assessment of carbon emission reductions following the implementation of a CE model with biogas production. The authors focused on large-scale pig farming in the Liaoning Province (China) and compared their findings with the traditional linear model. They show that significant carbon emission reductions and economic benefits could be realized by the application of a biogas-based CE model to animal husbandry.

\subsection{CE Barriers}

The transition towards a CE requires the overcoming of several barriers that the European Commission summarized as follows: the lack of skills and investments in designing products and processes for future re-use, the lack and unbalanced distribution of incentives, the low sensitivity of consumers, product obsolescence, the limited application of green public procurement and outdated legislation schemes [57]. According to Pieroni et al. [58], $\mathrm{CE}$ approaches are becoming more heterogeneous and rely on multiple theories that deviate from the traditional view disseminated by business model canvas. As an example, Mahpour [59] identified potential barriers for the transition to CE in C\&D WM starting from three main causes: behavioral, technical, and legal.

\subsubsection{Support from the Industrial Sector}

One of the main barriers to the implementation of $C E$ strategies is the lack of interest and awareness of the consumers and the hesitation of the industrial sectors in taking actions [60]. Sometimes, circular approaches must face the opposition of people when novel options for environmental sustainability are proposed, especially if such options encounter a consolidated scheme of values and traditions [61]. According to recent publications [62-64], the social pillar of sustainability is the least expanded in most of the conceptualizations and applications of the $\mathrm{CE}$, although the industrial sector does not agree with this point of view [65]. Although CE is at a relatively advanced stage, not every phase of the production sector, in industrial contexts implementing CE strategies, is characterized by circular approaches: this is the case, for instance, of the manufacturing and distribution phases in industry, which generally implements less circular strategies than other phases, like recovery, recycling, and consumption [66]. One exception is represented by companies organized in eco-industrial parks (EIPs). Indeed, at the industrial level, industrial symbiosis and industrial ecology (IE) initiatives offer opportunities for lowering the environmental impacts of industrial production [67-70], although such initiatives do not always lead to environmental benefits [71]. According to Ehrenfeld and Gertler [72], IE originated as an opportunity for different nearby firms to exchange energy, waste, and 
by-products, in order to optimize the use of resources and energy and obtain to clear economic and environmental advantages. Among many countries where IE initiatives have taken place, China developed a standard for eco-industrial parks and a dedicated set of indicators for qualitative assessment [73]. Saavedra et al. [74] studied the contribution of IE to CE through a bibliometric analysis covering 15 years (2003-2018), focusing on industrial symbiosis concepts (including urban symbiosis) and on the implementation of EIPs. According to Kapsalis et al. [75], industrial symbiosis could play a key role in connecting $\mathrm{CE}$ to ecosystem services, thus improving the environmental quality and the mutual interaction between biosphere and anthroposphere. IE, if combined with the concepts of eco-design and industry 4.0 [76], could considerably influence the achievement of higher sustainability goals in product manufacturing. According to Belaud et al. [77], big data management could offer support to IE: in their work, the authors applied big data management to evaluate the efficiency of enzymatic hydrolysis as a function of the pre-treatments of agricultural biomass over a 30 year period. However, when shifting from product manufacturing to WM and other environmental challenges, IE is not able to improve the current situation. Thus, the industrial sector (1) should contribute more to including CE principles in industrial processes, and (2) should study and implement symbiotic relationships among different industrial sectors.

\subsubsection{Support from Governments}

Blum et al. [78] affirm that CE can be considered as sustainable only if material circularity, economic sustainability, environmental sustainability and social sustainability are positively developed. A comprehensive $\mathrm{CE}$ approach can contribute to the solution to complex issues involving the Agenda 2030 topics through the creation of best practices, intended as methodologies to be applied to specific cases. The transition towards the application of comprehensive CE principles (including the social and environmental aspects) could be implemented gradually, as a series of small wins accumulating under a governance framework [79]. However, developing the core areas of sustainability is not enough if the transition is not supported by financial planning, reforms and a clear governance that considers CE as a crucial theme. CE-related initiatives require integrated bottom-up and top-down approaches to implementation and evaluation. Policy instruments (economic and regulatory instruments), such as subsidies and tax incentives, work when governments have clear objectives for policy processes that are evaluated and regulated, iteratively, to achieve short- and long-term goals [80]. Without an evaluation framework or bottom-up support from the industry or the community, CE initiatives are unlikely to be successfully implemented. As an example, Swainson and Mahanty [81] report the case of Indonesia, where institutional reforms were obstructed by vested interests committed to maintaining the existing political and economic status quo, and global markets offered insufficient premiums for a market-oriented green economy. Luttenberg [82] reviewed the WM transition to CE in Croatia. It showed limits in the implementation of public money to waste management systems and a lack of implementation of waste hierarchy with over-emphasis on residual waste treatment. Vermesan et al. [83] reviewed the implementation and the perspectives of CE in Romania. They showed that the objectives of the CE are still far from being fully implemented and that the legislation is still under improvement as well as the concept of CE, underlining that a circular model is still seen as a plus and not a standard of implementation. Ruiz-Real et al. [84] discussed the proactivity that China and the European Union (EU) are having in the development of legislation that develops and consolidates the implementation of the $\mathrm{CE}$ in their territories. However, the authors stress the need for better defining the areas and sectors that fall within the scope of CE. Zhu et al. [85] highlight that the actual Chinese policies still focus too much on the means, without paying enough attention to the ends and prospects of the CE. Increasing resource flows and production efficiency remain the core focus, while an optimal scale for sustainable consumption is often ignored. Bao and Lu [86] proposed the case study of Shenzhen (China) to discuss the urgency in fast-emerging economies to deal with an efficient circularity for C\&D WM. This 
can represent a further challenge in order to deal with fast population growth in several emerging countries. In conclusion, from the point of view of the institutional support, CE applications are slowed down by the following shortcomings: (1) the lack of an integrated vision of the problem considering all the pillars sustainability and (2) the lack of financial planning, reforms, and a clear governance supporting CE initiatives.

\section{4. $\mathrm{CE}_{\mathrm{L}}$ and Related Examples}

\subsection{The New Concept of $C E_{L}$}

One of the main differences between the concepts of $\mathrm{CE}$ and $\mathrm{CE}_{\mathrm{L}}$ is the declared intention of $\mathrm{CE}_{\mathrm{L}}$ to produce direct environmental benefits rather than pursuing economic sustainability. In fact, the symbiotic solution to environmental issues is expected to produce economic and social benefits too. A second difference consists in the focus on WM and on the conversion of waste into resources and energy, rather than optimizing resource and energy efficiency during product manufacturing [87]. $\mathrm{CE}_{\mathrm{L}}$ could be intended as an evolution of $\mathrm{CE}$ with a clear understanding of the direct and indirect environmental implications of sustainable strategies to manage waste, reuse materials, recover energy, and improve resource efficiency. $\mathrm{CE}_{\mathrm{L}}$, however, should not simply implement the concepts of remanufacturing, reuse, and recycling. It is an attempt to reinforce the need for CE initiatives that consider economic profit and environmental preservation (or environmental improvements, preferably) at the same level. To do this, it is necessary to overcome the barriers listed in Section 3.2. CE $\mathrm{L}_{\mathrm{L}}$ could also be intended as "ecological symbiosis" (as compared to industrial symbiosis), where environmental restoration processes work together to achieve specific environmental targets by maximizing resource efficiency and waste/material valorization. The concept of cleaner production could be considered as a pioneering approach to $\mathrm{CE}_{\mathrm{L}}$, because it involves the implementation of tools to decrease both the environmental pressure of industrialization and the costs related to inefficient use of resources [88]. This new approach could be seen as an integration of the paradigms analyzed in recent works by Blomsma [89] and Bruel et al. [90]. A comprehensive circular approach was provided by Bergendahl et al. [91] including several potential uses of waste from the food sector and the nexus with wastewater and the energy valorization of waste. The authors conclude that the role of transdisciplinary approaches is fundamental to implement sustainable supply chains. Though being analyzed at a regional/global level, the circular approach studied by the authors could translate into local practices of $\mathrm{CE}_{\mathrm{L}}$, especially if considering the nexus between food, energy and water investigated by the authors.

WM is the main field of application of the $\mathrm{CE}_{\mathrm{L}}$ concept. Cobo et al. [92] analyzed the challenges in implementing circular approaches in integrated municipal WM. According to the authors, the challenges consist in the limited boundaries of the traditional linear approach and on the very variable waste composition that requires the focus to shift from waste to resources.

The choice of the most appropriate alternative for specific $\mathrm{CE}_{\mathrm{L}}$ approaches can be supported by useful tools like Life Cycle Assessment (LCA) and Material Circularity Indicators. However, the correct application of these tools requires particular attention by the user, since one tool can give different results from the other. Lonca et al. [93] suggest that these tools should be considered as complementary rather than alternative.

The application of anaerobic digestion (AD) is probably one of the most immediate examples of $\mathrm{CE}_{\mathrm{L}}$ approach. $\mathrm{AD}$ allows converting biodegradable waste into energy and new material that can be used for agricultural purposes, as it is (digestate) or after a post-composting treatment. In addition, $\mathrm{AD}$ allows reducing the emissions of greenhouse gases with respect to landfilling and even composting [94]. Another example of $\mathrm{CE}_{\mathrm{L}}$ is the recovery of phosphorus $(\mathrm{P})$ from wastewater. On one hand, $\mathrm{P}$ is an essential element for fertilizers and other industrial uses; on the other hand, excess P causes eutrophication. Another well-known application of the $\mathrm{CE}_{\mathrm{L}}$ approach is the production of soil improvers from bio-waste, which is advantageous in terms of GHG emissions [95] and nitrogen 
contribution to soil with respect to commercial fertilizers [96]. Another interesting example of $\mathrm{CE}_{\mathrm{L}}$ consists in the production of biochar from organic waste and its potential use in several contexts [97].

\subsection{Practical Applications of $C E_{L}$ Approaches}

Tables 1-4 respectively report a set of case-study, laboratory-scale study, conceptual, and review papers that can be identified as $\mathrm{CE}_{\mathrm{L}}$ approaches. In total, 45 papers were selected as examples of works that propose approaches relevant to the concept of $\mathrm{CE}_{\mathrm{L}}$. Among the papers selected, 15 are case studies, nine are laboratory-scale studies, 19 are conceptual studies including theoretical considerations on potential $\mathrm{CE}_{\mathrm{L}}$ approaches, and the two remaining works are review papers. The majority of studies (37) focus on WM, including recycling and recovery processes. A minority of papers deal with other fields, such as wastewater management (4), water management (2), environmental remediation (1), and soil management (1). These papers were included anyway in our analysis as representative examples of the $\mathrm{CE}_{\mathrm{L}}$ concept. Most of the studies presented in Tables 1-4 were carried out in Europe (31). The remaining works were carried out in Brazil (3), China (4), Canada (1), Ecuador (1), Malaysia (1), Mexico (1), and multiple locations (3). 
Table 1. Summary of the case-study papers on the application of $\mathrm{CE}_{\mathrm{L}}$ principles.

\section{Field}

WM-Municipal solid waste

(cla

WM-Agroforestry
waste

\section{Summary}

A conventional wet AD process and a modified up-flow anaerobic sludge blanket reactor are compared for application to a small
the Covenant of Mayors initiative [98]. The wet process allows for higher biogas production but implies higher soil occupation.

The olive oil industry is an additional example of an industrial sector dealing with the environmental impacts caused by process byproducts. Different solutions (classified in a hierarchical way) are studied to reduce the problem of olive waste phytotoxicity, e.g., from energy valorization, to animal feed and higher-value products such as cosmetics and pharmaceuticals.

The authors recovered energy from the pruning of vineyards. The authors studied the combustion of pruning in a biomass-fueled Rankine cycle to produce heat and electric energy, which allows for revenues of about 80,000 $€$ /year and $\mathrm{CO}_{2}$ emission savings of about $1200 \mathrm{t} /$ year.

The authors propose a method for powering the public lighting of a Spanish district by exploiting the energy potential of olive mill effluents.

The authors describe an innovative process of pyrolysis of agricultural residues targeting biochar production, with the aim of closing the waste loop in agriculture. In a closed-loop pyrolysis-biochar system, the obtained biochar is directly returned to the same land that provided the feedstock.

WM-Zootechnical The authors studied an integrated approach to both valorize the waste coming from the broiler industry and reduce its impacts on the environment. An AD waste process applied to the waste and the subsequent separation of the liquid and solid phase of the digestate produce respectively a water-based liquid usable for irrigation and a soil improver of good quality.

The co-composting of rose waste with sawdust and different types of manure (chicken, hen and quail) were studied in detail. The process led to a compost

WM-Agro-

forestry and

zootechnical waste

particularly suitable for the cultivation of roses

The authors investigated the use of anaerobically-digested palm oil mill effluent in combination with chicken manure to produce an organic fertilizer. A 1:1 ratio between the two components resulted as the best choice in terms of soil fertility.

The conventional use of a solid-digestate from the AD of animal manures and vegetable biomass was compared with the biochar derived from the pyrolysis of the same digestate. The authors observed the relatively high carbon sequestration capacity of biochar, its higher surface area and water absorption capacity compared with solid-digestate, which make biochar preferable as a soil improver.

WM-Municipal The paper compares the AD of food waste with the co-digestion of food waste, pig manure and other organic waste. The second approach allowed obtaining

solid waste and lower GHG emissions than food waste mono-digestion ( $-6 \%)$. In addition, manure digestion allows reducing the costs for manure disposal, which in many zootechnical waste situations requires purchasing or rental.

In the city of Dalian (China), the local government has set measures to reduce water losses and increase water saving, such as using rainwater in agriculture, treated wastewater in industries using un-drinkable water in toilets.

WM The authors show that reusing wastewater and sewage sludge in agriculture, combined with bioenergy production, represents an added value to the agricultura sector, which can thus discard the use of fresh water and chemical fertilizers.

The paper proposes a tool for biogas plant investors/operators and local authorities to improve the sustainable use of organic fertilizers in agriculture and to decrease the use of mineral fertilizers. The approach may help local/regional/national authorities to develop control and support instruments for nutrient recycling to achieve $\mathrm{CE}$ goals.

WM-Recycling The authors studied the application of a digestate-derived biochar to the cultivation of maize. The authors demonstrated that improving the efficiency of waste recycling by combining $\mathrm{AD}$ with pyrolysis could be considered as a good practice of $\mathrm{CE}_{\mathrm{L}}$, since biochar could perfectly replace chemical fertilizers, which represent a loss of nutrients in contrast to digestate-derived biochar (which recycles nutrients). In addition, chemical fertilizers are known contributors of nitrates to soils and potential cause of aquifer contamination [96].

WM-C\&D The authors presented three European case study to illustrate the main types of construction interventions in a CE perspective. 
Table 2. Summary of the laboratory-scale study papers on the application of $\mathrm{CE}_{\mathrm{L}}$ principles.

The environmental performances of laboratory-scale processes were studied for polyphenols extraction from spruce bark by means of an LCA. The authors evaluated sustainable alternatives, showing that the greatest contributor in most impact categories was the electricity used to heat up the extraction systems, followed by solvent production and emissions (e.g., for the Soxhlet process).

WM-Agro-forestry

Direct combustion of olive pomace has been considered as the main process to exploit the energy content of such biomass in the past. However, waste thermochemical processes (e.g., pyrolysis and torrefaction) are preferable options, due to the higher energy density of the output fuel, which facilitates transportation and storage. The authors studied the application of such technologies and found ut that the heating value of the treated olive pomace was $60 \%$ higher than that of the untreated waste.

WM-Agro-forestry and The authors studied the co-digestion of sweet potato and cow manure. The addition of sweet potato determined an increase in the methane productivity of zootechnical waste up to $65.5 \%$. Meanwhile, the digestate showed higher contents of nitrogen, phosphorus, and potassium than cow-manure digestate.

Environmental remediation The authors investigated the adsorption of Vanadium (V) from aqueous solution by KOH modified seaweed (Ascophyllum nodosum) hydrochar (HCKOH). The results showed that $\mathrm{HCKOH}$ is an effective $\mathrm{V}$ adsorbent and that $\mathrm{V}$ recovery looks promising, as does the reusability of the $\mathrm{HCKOH}$, even though its mechanical stability may need to be improved.

A solvent-free catalyst-mediated method for the epoxidation of waste cooking oils and the production of sustainable polymers was developed. The process would allow recycling waste and, meanwhile, reducing the use of petroleum-based polymers.

The paper evaluates the feasibility of employing the biochar derived from agricultural and food waste as a soil improver. The authors observed no phytotoxic effects on the vegetable species considered (lettuce crops), but concluded that potentially harmful concentrations of heavy metals might limit the use of biochar in agriculture.

WM-Recycling and recovery
Different types of waste residues as a filling material for constructed wetlands were evaluated. The authors found out that fragments from construction activities, snail shells from the food industry, coal slags and residues from the cork industry show good adsorption potential for P and could be conveniently reused in the sanitary-environmental engineering sector.

A method was developed to regenerate waste expanded polystyrene. The method consists in the dissolution of polystyrene in styrene and in the subsequent suspension polymerization that allows incorporating styrene without the need to separate the polymer from its monomer. The process allows for a $92 \%$ recycling rate.

The paper discusses a new product, in the form of an artificial stone with good mechanical properties, made of oyster shells waste, used as a source of calcium carbonate and calcium oxide, mixed with an unsaturated polyester resin. 
Table 3. Summary of the conceptual study papers on the application of $\mathrm{CE}_{\mathrm{L}}$ principles.

Field

Soil management The aummary

The authors studied the role of soil/land management as a supplier of resources for the CE. They concluded that CE has a strong influence and, meanwhile, dependence on soils and land and that successful CE initiatives need an appropriate mutual management of soils, land, and resources.

The authors carried out an economic analysis on the production of biomethane from food waste and conclude that the economic sustainability of this sector is strongly influenced by the role of subsidies, especially at a small scale $\left(<200 \mathrm{Nm}^{3} / \mathrm{h}\right)$.

The study highlights the important role of an integrated system composed of the AD of the food waste and earthworms-enriched composting to obtain energy and a hormone-rich compost. The latter allows reducing the use of fertilizers in agriculture and connecting urban and rural areas.

The authors describe how the CE principles can affect the thermochemical waste sector. They argue on the need for more compact plants, able to treat waste with higher heating value and to turn ash into a product that can avoid landfill disposal.

The paper describes the role of sanitary textiles as a source-separated fraction under the viewpoint of urban waste production and proposes a recycling program coordinated with local recycling companies, with the main purpose of minimizing the residual waste fraction.

Drivers and barriers of P recovery were analyzed and the authors conclude that its implementation is currently hindered by the economic sustainability of the process, the rigidity of the fertilizer market and the acceptance of struvite as a fertilizer by stakeholders and the public.

The authors investigated alternative options for the recovery of $P$ from waste and wastewater, including the ash from sewage sludge, meat and bone meal, and the separation of urine at a household level.

WM

The authors present the potential opportunities related to the use of human excreta in Haiti and Kenya as a sanitation measure. However, this option has been facing a lack of regulation on this theme.

The urban region of Barcelona (Spain) has been used as case study to assess the technical and environmental feasibility of applying a struvite recovery and reuse strategy to meet the $\mathrm{P}$ requirements to fertilize the agricultural fields. The authors showed great savings in eutrophication since a great amount of $\mathrm{P}$ and part of the nitrogen was extracted from the effluent, thus preventing these nutrients from ending up in the aquatic environment.

WM-Zootechnical waste A proposal considering the local treatment of pig manure and slaughtering residues to produce soil improvers was formulated. The latter will be used to grow crops for pig feeding. Crops would be irrigated with the treated wastewater coming from pig waste treatments.

WM-Agro-forestry The paper discusses the availability of opportunities for improving the reduction of inorganic waste from intensive horticulture: a more efficient production waste with lower environmental impacts is possible, as it can be deduced from the best available techniques (BATs) presented in the research. 
Table 3. Cont.

Field Summary

The study assesses seaweed production and biorefinery systems producing bioethanol, liquid fertilizer and protein-rich fish feed. LCA identifies the ability of the system to provide climate change and marine eutrophication mitigation services, contributing to climate change mitigation by substitution of gasoline and soybean proteins, while returning excess atmospheric and marine carbon $\left(\mathrm{HCO}_{3}{ }^{-}\right)$into soil carbon stock.

The authors argue that most Danish river basin districts would benefit from seaweed cultivation, which would effectively contribute to the creation and maintenance of a nutrient balance for both nitrogen and $\mathrm{P}$, favoring the achievement of the EU nitrogen reduction goals.

WM-Recycling and recovery The authors discuss the use of available microalgae to produce valuable biochemical products. Their method represents an untapped potential that could lead to the solution of several problems through green technologies.

The authors present seaweed biorefinery systems as an opportunity to economically strengthen the agriculture, fishery, chemical and energy sectors, while helping the recycling of nutrients and alleviating environmental issues.

The paper proposes a roadmap that may help adjust the choice of nutrient recovery strategies to local fertilizer markets, thereby speeding up the transition from a fossil-based to a bio-based nutrient CE.

The authors proposed six research topics for future directions: (i) C\&D waste generation, (ii) C\&D waste treatment methods, (iii) products containing recycled contents, (iv) C\&D WM practice, (v) human factors in C\&D WM, and (vi) emerging technologies or concepts to be applied in C\&D WM. The authors present a new methodology aiming to measure the long-term sustainability of construction companies, and the related degree of implementation of CE.

The authors reviewed alternative C\&D WM in China in order to evaluate the transition towards a cleaner production and a CE. They identified four main types of barriers in the implementation of C\&D WM: (i) political and market, (ii) financial and economic, (iii) technical and information and (iv) managerial and organizational barriers.

WM-C\&D

Table 4. Summary of the review papers on the application of $\mathrm{CE}_{\mathrm{L}}$ principles.

\section{Field}

WM-Recycling and recovery

\section{Summary}

Biochars were studied as a promising alternative to commercial activated carbon, thanks to their good adsorption capabilities of heavy metals and organic compounds, including pharmaceutical products, and their easy regeneration. However, the same authors state that the selection of the input waste for the production of biochar should be made carefully in order to obtain a biochar with a low content of metals.

The authors reviewed several case studies involving the bioconversion of different types of waste streams to valuable products. The authors mention the bioconversion of flour-rich streams from the bread and confectionery industry. The authors report that flour-rich streams have been used in several applications such as bacterial cellulose production, microbial oil for biofuel production and new yeasts. The same authors report that wine less has been used to produce substances like antioxidants, ethanol, and tartrate salts. 


\section{Discussion and Future Challenges}

The publications summarized in Tables 1-4 present different methods to solve environmental problems through circular approaches and combining heterogeneous processes, i.e., by applying $\mathrm{CE}_{\mathrm{L}}$ principles. Among the papers proposing new circular approaches for $\mathrm{WM}$, the majority of them propose solutions to generate valuable products (e.g., adsorption materials, cellulose, chemicals, biofuels, fertilizers and soil improvers from agro-forestry, and zootechnical and food waste) $[97,99,102-106,110,111,113,117-121,124,131,133,135,141]$, recover precious nutrients $[128,134,136,137]$, exploiting sustainable sources of energy [45, $100,101,109,110,114,115,123,125]$, and eliminate residual waste $[112,126,129,132,138-140]$.

Additional fields are expected to benefit from the application of $\mathrm{CE}_{\mathrm{L}}$ approaches. For instance, hydrochars and biochars derived from waste biomass could be used as adsorbents for organic and inorganic pollutants in soils and sediments, thus allowing for environmental remediation procedures. Waste biomass has the advantage of being available in many geographical contexts and could be fed locally to hydrothermal carbonization (HTC) or pyrolysis processes. As an example, eutrophic lakes characterized by the growth of invasive vegetable species could represent a source of waste biomass, which could be converted into hydrochars or biochars. The latter could be used in a wide range of applications. Additional potential sources of waste biomass are (but not limited to) agro-forestry residues, food and food processing residues, zootechnical waste, and seaweeds. Excess biomass (technically a waste) represents an issue for rivers and canals, too, and should be harvested regularly to avoid hydraulic risks related to section narrowing and increased bank roughness. Thus, eco-morphodynamics could be an additional interesting field of application of the $\mathrm{CE}_{\mathrm{L}}$ concept.

In the perspective of reducing the carbon emissions, improving resource efficiency, minimizing waste production and potential damages to soils, another interesting opportunity of $\mathrm{CE}_{\mathrm{L}}$ approaches consists in the optimization of the different circuits available to valorize zootechnical waste, whose contribution to local air pollution, odors, greenhouse gas emissions, and nitrate contamination of soils and aquifers are known. In this regard, an innovative approach is suggested by a recent paper, consisting in the coupling of the HTC of swine manure with the AD of OFMSW to produce energy, compost, and hydrochar [142]. Both compost and hydrochar could be used locally for agricultural applications, thus closing the cycle of the organic waste in a rural context.

The possibilities for the application of $\mathrm{CE}_{\mathrm{L}}$ principles and their export to different geographical contexts are wide and significant environmental benefits are expected. Ghisellini et al. [143] reviewed if the application of CE to construction and demolition sector is environmentally and economically sustainable. They show that the result of the analyses is site-specific and depends on several factors such as the type of material, building elements, transport distances, economic and political context. Moreover, an integrated framework aiming to stimulate effective collaborations between companies, policymakers, governments, and scientists is needed [144].

The path towards successful $\mathrm{CE}_{\mathrm{L}}$ applications is characterized by the presence of barriers. First of all, adequate reforms in the environmental legislations are needed to support the commercialization of new products deriving from biowaste recycling operations (e.g., the use of bio-based hydrochars in agriculture). Planning $\mathrm{CE}_{\mathrm{L}}$ strategies also requires a deep level of awareness of how the societal, economic, industrial, and environmental frameworks may evolve in the long-term. This should be considered especially in developing countries, where rapid industrialization might put $\mathrm{CE}_{\mathrm{L}}$ principles on a secondary level. In addition, $\mathrm{CE}_{\mathrm{L}}$ approaches require the legislative and financial support to scientific research and initiatives provided by a clear governance, possibly at a global level and characterized by stronger motivations than those that allowed for the approval of the Agenda 2030. In this sense, funding schemes like the EU LIFE and EU Horizon 2020 programs are great opportunities to experiment new approaches aimed at waste reuse and recycling, resource efficiency and the consequent waste reduction, and solving environmental problems with the least possible impacts on the environment itself, by 
the implementation of innovative processes or smart combinations of existing processes. Furthermore, the implementation of $\mathrm{CE}_{\mathrm{L}}$ initiatives at a local level would allow reducing the emissions of local and global air pollutants related to transport. As highlighted by the quality of the papers on these topics, the level of innovation in processes dealing with WM, resource and energy recovery is high and this represents a good starting point for further research. Local governments should take in the results of such projects and support the replication of successful ideas in other contexts and at a larger scale.

\section{Conclusions}

The paper critically discussed the concept of CE with a specific focus on WM. From a literature review on $\mathrm{CE}$ principles, a large number of barriers emerge, which governments should consider to complete a transition that seems still far to be achieved. In particular, according to several authors, $\mathrm{CE}$ has shown a lack of focus on two of the three pillars which the original formulation of $\mathrm{CE}$ is based on, i.e., social and environmental sustainability. $\mathrm{CE}$ is meant to deal with combining economic and environmental benefits, but this does not necessarily mean that every application of CE principles deals with it. This is mainly due to the barriers described in Section 3.2. The present paper specifically addressed the lack of attention of the industry and the lack of a governance framework and investment plans willing to face today's environmental challenges, and proposed the new concept of $\mathrm{CE}_{\mathrm{L}}$ as an alternative pathway to compensate for this imbalance. Extending the principles behind the virtuous WM choices presented in Section 4.2 to other sectors would increase the level of environmental sustainability of $\mathrm{CE}$ and would help to define more environmentally sustainable strategies. Proposing a new concept $\left(\mathrm{CE}_{\mathrm{L}}\right)$ could be a useful way to promote the idea behind and reinforce the need for more attention to the environmental sphere.

Although $\mathrm{CE}_{\mathrm{L}}$ is defined for the first time in the present paper, several publications have already discussed case studies, conceptual frameworks and laboratory-scale experiences aimed at facing environmental challenges through circular approaches. The majority of the papers reviewed on this topic focus on circular approaches applicable to WM, considering new recycling options, the production of new valuable material, combined waste treatment processes (in some cases working in a symbiotic mode) and new energy recovery options from waste biomass. New guidelines for future research were proposed, such as the need for optimizing the valorization of agro-forestry and zootechnical waste, the opportunity to restore local contexts subjected to environmental pollution through the reuse of waste biomass, and the importance of applying circular approaches locally, by exploiting the resources provided by waste. This would allow reducing transport-related emissions and finding a solution to the production of waste, which could be employed in environmental remediation strategies, to produce new valuable resources or to generate energy. If properly supported by governments, $\mathrm{CE}_{\mathrm{L}}$ approaches may represent an opportunity to solve multiple environmental problems at once, with clear economic, time, resources, and emission savings.

Author Contributions: Conceptualization: L.A. and M.S.; methodology: L.A. and M.S.; validation: L.A. and M.S.; formal analysis: L.A. and M.S.; investigation: L.A. and M.S.; resources: L.A. and M.S.; data curation: L.A. and M.S.; writing-original draft preparation: L.A. and M.S.; writing-review and editing: L.A. and M.S. Both authors have read and agreed to the published version of the manuscript.

Funding: This research received no external funding.

Institutional Review Board Statement: Not applicable.

Informed Consent Statement: Not applicable.

Data Availability Statement: No new data were created or analyzed in this study. Data sharing is not applicable to this article.

Conflicts of Interest: The authors declare no conflict of interest. 


\section{References}

1. Scopus. 2020. Available online: https:/ /www.scopus.com (accessed on 5 October 2020).

2. Homrich, A.S.; Galvão, G.; Abadia, L.G.; Carvalho, M.M. The circular economy umbrella: Trends and gaps on integrating pathways. J. Clean. Prod. 2018, 175, 525-543. [CrossRef]

3. Parchomenko, A.; Nelen, D.; Gillabel, J.; Rechberger, H. Measuring the Circular Economy-A Multiple Correspondence Analysis of 63 Metrics. J. Clean. Prod. 2019, 210, 200-216. [CrossRef]

4. Boulding, K.E. The Impact of the Social Sciences, 3rd ed.; The Social Sciences and the Social System 3-23; Rutgers University Press: New Brunswick, NJ, USA, 1966; ISBN 978-08-1350-525-1.

5. Leontief, W. The economy as a circular flow. Struct. Change Econ. Dyn. 1991, 2, 181-212. [CrossRef]

6. Ellen MacArthur Foundation. Towards the Circular Economy. Economic and business rationale for an accelerated transition. J. Ind. Ecol. 2013, 2, 1-98.

7. United Nations. Transforming Our World: The 2030 Agenda for Sustainable Development. 2015. Available online: https: //www.un.org/ga/search/view_doc.asp?symbol=A/RES/70/1\&Lang=E (accessed on 19 November 2020).

8. Griggs, D.; Stafford-Smith, M.; Gaffney, O.; Rockström, J.; Öhman, M.C.; Shyamsundar, P.; Steffen, W.; Glaser, G.; Kanie, N.; Noble, I. Policy: Sustainable development goals for people and planet. Nature 2013, 495, 305-307. [CrossRef]

9. United Nations. The Sustainable Development Agenda. 2020. Available online: https://www.un.org/sustainabledevelopment/ development-agenda/ (accessed on 19 November 2020).

10. Birat, J.P. Life-Cycle Assessment, Resource Efficiency and Recycling. Metall. Res. Tech. 2015, 112, 206. [CrossRef]

11. Ferronato, N.; Rada, E.C.; Gorritty Portillo, M.A.; Cioca, L.I.; Ragazzi, M.; Torretta, V. Introduction of the Circular Economy within Developing Regions: A Comparative Analysis of Advantages and Opportunities for Waste Valorization. J. Environ. Manag. 2019, 230, 366-378. [CrossRef]

12. Cheng, H.; Dong, S.; Li, F.; Yang, Y.; Li, Y.; Li, Z. A Circular Economy System for Breaking the Development Dilemma of 'Ecological Fragility-Economic Poverty' Vicious Circle: A CEEPS-SD Analysis. J. Clean. Prod. 2019, 212, 381-392. [CrossRef]

13. Geng, Y.; Doberstein, B. Developing the Circular Economy in China: Challenges and Opportunities for Achieving 'Leapfrog Development'. Int. J. Sustain. Dev. World Ecol. 2008, 15, 231-239. [CrossRef]

14. European Commission. Directive 2008/98/EC of the European Parliament and of the Council of 19 November 2008 on Waste and Repealing Certain Directives (Text with EEA Relevance). 2008. Available online: https:/ / eur-lex.europa.eu/legal-content/EN/ TXT/HTML/?uri=CELEX:32008L0098\&from=EN (accessed on 19 November 2020).

15. Merli, R.; Preziosi, M.; Acampora, A. How do Scholars Approach the Circular Economy? A Systematic Literature Review. J. Clean. Prod. 2018, 178, 703-722. [CrossRef]

16. Aguilar-Hernandez, G.A.; Sigüenza-Sanchez, C.P.; Donati, F.; Merciai, S.; Schmidt, J.; Rodrigues, J.F.D.; Tukker, A. The Circularity Gap of Nations: A Multiregional Analysis of Waste Generation, Recovery, and Stock Depletion in 2011. Resour. Conserv. Recycl. 2019, 151. [CrossRef]

17. Jander, W.; Grundmann, P. Monitoring the Transition Towards a Bioeconomy: A General Framework and a Specific Indicator. J. Clean. Prod. 2019, 236, 117564. [CrossRef]

18. Vanhamaki, S.; Medkova, K.; Malamakis, A.; Kontogianni, S.; Marisova, E.; Dellago, D.H.; Moussiopoulos, N. Bio-Based Circular Economy in European National and Regional Strategies. Int. J. Sustain. Dev. Plan. 2019, 14, 31-43. [CrossRef]

19. De Jesus, A.; Mendonça, S. Lost in Transition? Drivers and Barriers in the Eco-innovation Road to the Circular Economy. Ecol. Econ. 2018, 145, 75-89. [CrossRef]

20. Farooque, M.; Zhang, A.; Thürer, M.; Qu, T.; Huisingh, D. Circular Supply Chain Management: A Definition and Structured Literature Review. J. Clean. Prod. 2019, 228, 882-900. [CrossRef]

21. Franco, M.A. A System Dynamics Approach to Product Design and Business Model Strategies for the Circular Economy. J. Clean. Prod. 2019, 241. [CrossRef]

22. Gupta, S.; Chen, H.; Hazen, B.T.; Kaur, S.; Santibañez Gonzalez, E.D.R. Circular Economy and Big Data Analytics: A Stakeholder Perspective. Tech. Forecast. Soc. Chang. 2019, 144, 466-474. [CrossRef]

23. Millar, N.; McLaughlin, E.; Börger, T. The Circular Economy: Swings and Roundabouts? Ecol. Econ. 2019, 158, 11-19. [CrossRef]

24. Horvath, B.; Bahna, M.; Fogarassy, C. The Ecological Criteria of Circular Growth and the Rebound Risk of Closed Loops. Sustainability 2019, 11, 2961. [CrossRef]

25. Corona, B.; Shen, L.; Reike, D.; Rosales Carreón, J.; Worrell, E. Towards sustainable development through the circular economy-A review and critical assessment on current circularity metrics. Res. Cons. Recycl. 2019, 151. [CrossRef]

26. Kallis, G. In Defence of Degrowth. Ecol. Econ. 2011, 70, 873-880. [CrossRef]

27. Kerschner, C. Economic de-growth vs. steady-state economy. J. Clean. Prod. 2010, 18, 544-551. [CrossRef]

28. Kiser, B. Circular Economy: Getting the Circulation Going. Nature 2016, 531, 443-446. [CrossRef]

29. Skene, K.R. Circles, Spirals, Pyramids and Cubes: Why the Circular Economy Cannot Work. Sustain. Sci. 2018, 13, 479-492. [CrossRef]

30. Ali, S.H.; Puppim De Oliveira, J.A. Pollution and Economic Development: An Empirical Research Review. Environ. Res. Lett. 2018, 13. [CrossRef]

31. PRISMA. Preferred Reporting Items for Systematic Reviews and Meta-Analyses. 2020. Available online: http:/ / www.prismastatement.org/ (accessed on 19 November 2020).

32. Orsini, F.; Marrone, P. Approaches for a Low-Carbon Production of Building Materials: A Review. J. Clean. Prod. 2019, 241. [CrossRef] 
33. Paletta, A.; Leal Filho, W.; Balogun, A.L.; Foschi, E.; Bonoli, A. Barriers and Challenges to Plastics Valorisation in the Context of a Circular Economy: Case Studies from Italy. J. Clean. Prod. 2019, 241. [CrossRef]

34. Tseng, M.-L.; Chang, C.-H.; Wu, K.-J.; Remen Lin, C.-W.; Kalnaovkul, B.; Tan, R.R. Sustainable Agritourism in Thailand: Modeling Business Performance and Environmental Sustainability Under Uncertainty. Sustainability 2019, 11, 4087. [CrossRef]

35. Valls, J.-F.; Mota, L.; Vieira, S.C.F.; Santos, R. Opportunities for Slow Tourism in Madeira. Sustainability 2019, 11, 4534. [CrossRef]

36. Roseland, M. Dimensions of the eco-city. Cities 1997, 14, 197-202. [CrossRef]

37. Zhijun, F.; Nailing, Y. Putting a circular economy into practice in China. Sustain. Sci. 2007, 2, 95-101. [CrossRef]

38. Petit-Boix, A.; Leipold, S. Circular Economy in Cities: Reviewing how Environmental Research Aligns with Local Practices. J. Clean. Prod. 2018, 195, 1270-1281. [CrossRef]

39. Zambon, I.; Colantoni, A.; Cecchini, M.; Mosconi, E.M. Rethinking Sustainability within the Viticulture Realities Integrating Economy, Landscape and Energy. Sustainability 2018, 10, 320. [CrossRef]

40. Esposito, B.; Sessa, M.R.; Sica, D.; Malandrino, O. Towards Circular Economy in the Agri-Food Sector. A Systematic Literature Review. Sustainability 2020, 12, 7401. [CrossRef]

41. Ryen, E.G.; Gaustad, G.; Babbitt, C.W.; Babbitt, G. Ecological Foraging Models as Inspiration for Optimized Recycling Systems in the Circular Economy. Resour. Conserv. Recycl. 2018, 135, 48-57. [CrossRef]

42. Ng, K.S.; Yang, A.; Yakovleva, N. Sustainable Waste Management through Synergistic Utilisation of Commercial and Domestic Organic Waste for Efficient Resource Recovery and Valorisation in the UK. J. Clean. Prod. 2019, 227, 248-262. [CrossRef]

43. Prieto-Sandoval, V.; Jaca, C.; Ormazabal, M. Towards a Consensus on the Circular Economy. J. Clean. Prod. 2018, 179, 605-615. [CrossRef]

44. Pires, A.; Martinho, G. Waste hierarchy index for circular economy in waste management. Waste Manag. 2019, 95, 298-305. [CrossRef]

45. Adami, L.; Schiavon, M.; Torretta, V.; Costa, L.; Rada, E.C. Evaluation of conventional and alternative anaerobic digestion technologies for applications to small and rural communities. Waste Manag. 2020, 118, 79-89. [CrossRef]

46. Taelman, S.E.; Tonini, D.; Wandl, A.; Dewulf, J. A holistic sustainability framework for waste management in european cities: Concept development. Sustainability 2018, 10, 2184. [CrossRef]

47. Tisserant, A.; Pauliuk, S.; Merciai, S.; Schmidt, J.; Fry, J.; Wood, R.; Tukker, A. Solid waste and the circular economy: A global analysis of waste treatment and waste footprints. J. Ind. Ecol. 2017, 21, 628-640. [CrossRef]

48. Reh, L. Process engineering in circular economy. Particuology 2013, 11, 119-133. [CrossRef]

49. Stahel, W.R. Circular economy. Nature 2016, 531, 435-438. [CrossRef] [PubMed]

50. Ranta, V.; Aarikka-Stenroos, L.; Mäkinen, S.J. Creating value in the circular economy: A structured multiple-case analysis of business models. J. Clean. Prod. 2018, 201, 988-1000. [CrossRef]

51. Aslam, M.S.; Huang, B.; Cui, L. Review of construction and demolition waste management in China and USA. J. Environ. Manag. 2020, 264. [CrossRef]

52. Gálvez-Martos, J.L.; Styles, D.; Schoenberger, H.; Zeschmar-Lahl, B. Construction and demolition waste best management practice in Europe. Resour. Conserv. Recycl. 2018, 136, 166-178. [CrossRef]

53. López Ruiz, L.A.; Roca Ramón, X.; Gassó Domingo, S. The circular economy in the construction and demolition waste sector-A review and an integrative model approach. J. Clean. Prod. 2020, 248. [CrossRef]

54. Ubando, A.T.; Felix, C.B.; Chen, W. Biorefineries in circular bioeconomy: A comprehensive review. Biores. Technol. 2020, 299. [CrossRef]

55. Wainaina, S.; Awasthi, M.K.; Sarsaiya, S.; Chen, H.; Singh, E.; Kumar, A.; Ravindran, B.; Awasthi, S.K.; Liu, T.; Duan, Y.; et al. Resource recovery and circular economy from organic solid waste using aerobic and anaerobic digestion technologies. Biores. Technol. 2020, 301. [CrossRef]

56. Xue, Y.; Luan, W.; Wang, H.; Yang, Y. Environmental and economic benefits of carbon emission reduction in animal husbandry via the circular economy: Case study of pig farming in Liaoning, China. J. Clean. Prod. 2019, 238. [CrossRef]

57. European Commission. Towards a Circular Economy: A Zero Waste Programme for Europe. 2014. Available online: https: / / ec.europa.eu/environment/ circular-economy/pdf/circular-economy-communication.pdf (accessed on 17 November 2020).

58. Pieroni, M.P.P.; McAloone, T.C.; Pigosso, D.C.A. Business model innovation for circular economy and sustainability: A review of approaches. J. Clean. Prod. 2019, 215, 198-216. [CrossRef]

59. Mahpour, A. Prioritizing barriers to adopt circular economy in construction and demolition waste management. Resour. Conserv. Recycl. 2019, 134, 216-227. [CrossRef]

60. Kirchherr, J.; Piscicelli, L.; Bour, R.; Kostense-Smit, E.; Muller, J.; Huibrechtse-Truijens, A.; Hekkert, M. Barriers to the circular economy: Evidence from the European Union (EU). Ecol. Econ. 2018, 150, 264-272. [CrossRef]

61. Asai, M.; Hayashi, T.; Yamamoto, M. Mental model analysis of biogas energy perceptions and policy reveals potential constraints in a Japanese farm community. Sustainability 2019, 11, 225. [CrossRef]

62. Murray, A.; Skene, K.; Haynes, K. The circular economy: An interdisciplinary exploration of the concept and application in a global context. J. Bus. Ethics 2017, 140, 369-380. [CrossRef]

63. Swagemakers, P.; Garcia, M.D.D.; Wiskerke, J.S.C. Socially-inclusive development and value creation: How a composting project in Galicia (Spain) 'Hit the rocks'. Sustainability 2018, 10, 2040. [CrossRef] 
64. Schulz, C.; Hjaltadóttir, R.E.; Hild, P. Practising circles: Studying institutional change and circular economy practices. J. Clean. Prod. 2019, 237. [CrossRef]

65. Näyhä, A. Transition in the finnish forest-based sector: Company perspectives on the bioeconomy, circular economy and sustainability. J. Clean. Prod. 2019, 209, 1294-1306. [CrossRef]

66. Kalmykova, Y.; Sadagopan, M.; Rosado, L. Circular economy-from review of theories and practices to development of implementation tools. Resour. Conserv. Recycl. 2018, 135, 190-201. [CrossRef]

67. Chertow, M.R. Industrial symbiosis: Literature and taxonomy. Annu. Rev. Energy Environ. 2000, 25, 313-337. [CrossRef]

68. Chiu, A.S.F.; Yong, G. On the industrial ecology potential in Asian developing countries. J. Clean. Prod. 2004, 12, 1037-1045. [CrossRef]

69. Behera, S.K.; Kim, J.; Lee, S.; Suh, S.; Park, H. Evolution of 'designed' industrial symbiosis networks in the ulsan eco-industrial park: 'research and development into business' as the enabling framework. J. Clean. Prod. 2012, 29-30, 103-112. [CrossRef]

70. Domenech, T.; Bleischwitz, R.; Doranova, A.; Panayotopoulos, D.; Roman, L. Mapping industrial symbiosis development in Europe: Typologies of networks, characteristics, performance and contribution to the circular economy. Resour. Conserv. Recycl. 2019, 141, 76-98. [CrossRef]

71. Bai, L.; Qiao, Q.; Yao, Y.; Guo, J.; Xie, M. Insights on the development progress of National Demonstration eco-industrial parks in China. J. Clean. Prod. 2014, 70, 4-14. [CrossRef]

72. Ehrenfeld, J.; Gertler, N. Industrial ecology in practice: The evolution of interdependence at kalundborg. J. Ind. Ecol. 1997, 1, 67-79. [CrossRef]

73. Huang, B.; Yong, G.; Zhao, J.; Domenech, T.; Liu, Z.; Chiu, S.F.; McDowallc, W.; Bleischwitzc, R.; Liuf, J.; Yao, Y. Review of the development of china's eco-industrial park standard system. Resour. Conserv. Recycl. 2019, 140, 137-144. [CrossRef]

74. Saavedra, Y.M.B.; Iritani, D.R.; Pavan, A.L.R.; Ometto, A.R. Theoretical contribution of industrial ecology to circular economy. J. Clean. Prod. 2018, 170, 1514-1522. [CrossRef]

75. Kapsalis, V.C.; Kyriakopoulos, G.L.; Aravossis, K.G. Investigation of ecosystem services and circular economy interactions under an inter-organizational framework. Energies 2019, 12, 1734. [CrossRef]

76. Garcia-Muiña, F.E.; González-Sánchez, R.; Ferrari, A.M.; Volpi, L.; Pini, M.; Siligardi, C.; Settembre-Blundo, D. Identifying the equilibrium point between sustainability goals and circular economy practices in an industry 4.0 manufacturing context using eco-design. Soc. Sci. 2019, 8, 241. [CrossRef]

77. Belaud, J.; Prioux, N.; Vialle, C.; Sablayrolles, C. Big data for agri-food 4.0: Application to sustainability management for by-products supply chain. Comput. Ind. 2019, 111, 41-50. [CrossRef]

78. Blum, N.U.; Haupt, M.; Bening, C.R. Why “Circular" doesn't always mean "Sustainable". Resour. Conserv. Recycl. 2020, 162. [CrossRef]

79. Termeer, C.J.A.M.; Metze, T.A.P. More than peanuts: Transformation towards a circular economy through a small-wins governance framework. J. Clean. Prod. 2019, 240. [CrossRef]

80. Winans, K.; Kendall, A.; Deng, H. The history and current applications of the circular economy concept. Renew. Sust. Energy Rev. 2017, 68, 825-833. [CrossRef]

81. Swainson, L.; Mahanty, S. Green economy meets political economy: Lessons from the "Aceh green" initiative, Indonesia. Glob. Environ. Chang. 2018, 53, 286-295. [CrossRef]

82. Luttenberger, L.R. Waste management challenges in transition to circular economy-Case of Croatia. J. Clean. Prod. 2020, 256. [CrossRef]

83. Vermeşan, H.; Mangău, A.; Tiuc, A. Perspectives of circular economy in Romanian space. Sustainability 2020, 12, 6819. [CrossRef]

84. Ruiz-Real, J.L.; Uribe-Toril, J.; Valenciano, J.D.P.; Gázquez-Abad, J.C. Worldwide research on circular economy and environment: A bibliometric analysis. Int. J. Environ. Res. Public Health 2018, 15, 2699. [CrossRef]

85. Zhu, J.; Fan, C.; Shi, H.; Shi, L. Efforts for a circular economy in China: A comprehensive review of policies. J. Ind. Ecol. 2019, 23, 110-118. [CrossRef]

86. Bao, Z.; Lu, W. Developing efficient circularity for construction and demolition waste management in fast emerging economies: Lessons learned from Shenzhen, China. Sci. Tot. Environ. 2020, 724. [CrossRef]

87. Geissdoerfer, M.; Savaget, P.; Bocken, N.M.P.; Hultink, E.J. The circular economy-A new sustainability paradigm? J. Clean. Prod. 2017, 143, 757-768. [CrossRef]

88. Fresner, J. Cleaner production as a means for effective environmental management. J. Clean. Prod. 1998, 6, 171-179. [CrossRef]

89. Blomsma, F. Collective 'action recipes' in a circular economy-On waste and resource management frameworks and their role in collective change. J. Clean. Prod. 2018, 199, 969-982. [CrossRef]

90. Bruel, A.; Kronenberg, J.; Troussier, N.; Guillaume, B. Linking industrial ecology and ecological economics: A theoretical and empirical foundation for the circular economy. J. Ind. Ecol. 2019, 23, 12-21. [CrossRef]

91. Bergendahl, J.A.; Sarkis, J.; Timko, M.T. Transdisciplinarity and the food energy and water nexus: Ecological modernization and supply chain sustainability perspectives. Resour. Conserv. Recycl. 2018, 133, 309-319. [CrossRef]

92. Cobo, S.; Dominguez-Ramos, A.; Irabien, A. From linear to circular integrated waste management systems: A review of methodological approaches. Resour. Conserv. Recycl. 2018, 135, 279-295. [CrossRef]

93. Lonca, G.; Muggéo, R.; Imbeault-Tétreault, H.; Bernard, S.; Margni, M. Does material circularity rhyme with environmental efficiency? Case studies on used tires. J. Clean. Prod. 2018, 183, 424-435. [CrossRef] 
94. Rena, S.A.; Chavan, D.; Aiman, S.; Kumar, S. Reducing Greenhouse Gas Emission From Waste Landfill. Reducing Greenhouse Gas Emission from Waste Landfill. Encycl. Renew. Sustain. Mater. 2020, 3, 685-701. [CrossRef]

95. Diacono, M.; Persiani, A.; Testani, E.; Montemurro, F.; Ciaccia, C. Recycling agricultural wastes and by-products in organic farming: Biofertilizer production, yield performance and carbon footprint analysis. Sustainability 2019, 11, 3824. [CrossRef]

96. Galsim, F.; Golabi, M.H.; Kim, Y.S.; Iyekar, C. Comparative effects of composted organic waste and inorganic fertilizer on nitrate leachate from the farm soils of northern Guam. Int. Soil Water Cons. Res. 2020, in press. [CrossRef]

97. Fdez-Sanromán, A.; Pazos, M.; Rosales, E.; Sanromán, M.A. Unravelling the environmental application of biochar as low-cost biosorbent: A review. Appl. Sci. 2020, 10, 7810. [CrossRef]

98. Adami, L.; Castagna, G.; Magaril, E.; Giurea, R.; Ferronato, N.; Ruggieri, G.; Torretta, V.; Rada, E.C. Criticalities and potentialities of local renewable sources of energy. WIT Trans. Ecol. Environ. 2019, 222, 103-115. [CrossRef]

99. Berbel, J.; Posadillo, A. Review and analysis of alternatives for the valorisation of agro-industrial olive oil by-products. Sustainability 2018, 10, 237. [CrossRef]

100. Lamagna, M.; Carlucci, M.; Groppi, D.; Garcia, D.A. Social and Economic Impact of a Waste-to-Energy Strategy Applied to the Winemaking Chain: A Case Study in the Italian Countryside. In Proceedings of the 1st International Conference on Energy Transition in the Mediterranean Area (SyNERGY MED), Cagliari, Italy, 28-30 May 2019; pp. 1-6. [CrossRef]

101. Molina-Moreno, V.; Leyva-Díaz, J.C.; Llorens-Montes, F.J.; Cortés-García, F.J. Design of indicators of circular economy as instruments for the evaluation of sustainability and efficiency in wastewater from pig farming industry. Water 2017, 9, 653. [CrossRef]

102. Zabaniotou, A.; Rovas, D.; Libutti, A.; Monteleone, M. Boosting circular economy and closing the loop in agriculture: Case study of a small-scale pyrolysis-biochar based system integrated in an olive farm in symbiosis with an olive mill. Environ. Dev. 2015, 14, 22-36. [CrossRef]

103. Cuadros Blázquez, F.; González González, A.; Sánchez Sánchez, C.; Díaz Rodríguez, V.; Cuadros Salcedo, F. Waste valorization as an example of circular economy in extremadura (Spain). J. Clean. Prod. 2018, 181, 136-144. [CrossRef]

104. Idrovo-Novillo, J.; Gavilanes-Terán, I.; Angeles Bustamante, M.; Paredes, C. Composting as a method to recycle renewable plant resources back to the ornamental plant industry: Agronomic and economic assessment of composts. Process Saf. Environ. Prot. 2018, 116, 388-395. [CrossRef]

105. Loh, S.K.; Lai, M.E.; Ngatiman, M. Vegetative growth enhancement of organic fertilizer from anaerobically-treated palm oil mill effluent (POME) supplemented with chicken manure in food-energy-water nexus challenge. Food Bioprod. Process 2019, 117, 95-104. [CrossRef]

106. Monlau, F.; Francavilla, M.; Sambusiti, C.; Antoniou, N.; Solhy, A.; Libutti, A.; Zabaniotou, A.; Barakat, A.; Monteleone, M. Toward a functional integration of anaerobic digestion and pyrolysis for a sustainable resource management. comparison between solid-digestate and its derived pyrochar as soil amendment. Appl. Energy 2016, 169, 652-662. [CrossRef]

107. Moretti, M.; Van Dael, M.; Malina, R.; Van Passel, S. Environmental assessment of waste feedstock mono-dimensional and bio-refinery systems: Combining manure co-digestion and municipal waste anaerobic digestion. J. Clean. Prod. 2018, 171, 954-961. [CrossRef]

108. Geng, Y.; Zhu, Q.; Doberstein, B.; Fujita, T. Implementing China's circular economy concept at the regional level: A review of progress in Dalian, China. Waste Manag. 2009, 29, 996-1002. [CrossRef]

109. Maaß, O.; Grundmann, P. Added-value from linking the value chains of wastewater treatment, crop production and bioenergy production: A case study on reusing wastewater and sludge in crop production in Braunschweig (Germany). Resour. Conserv. Recycl. 2016, 107, 195-211. [CrossRef]

110. Tampio, E.; Lehtonen, E.; Kinnunen, V.; Mönkäre, T.; Ervasti, S.; Kettunen, R.; Rasi, S.; Rintala, J. A demand-based nutrient utilization approach to urban biogas plant investment based on regional crop fertilization. J. Clean. Prod. 2017, 164, 19-29. [CrossRef]

111. Kizito, S.; Luo, H.; Lu, J.; Bah, H.; Dong, R.; Wu, S. Role of nutrient-enriched biochar as a soil amendment during maize growth: Exploring practical alternatives to recycle agricultural residuals and to reduce chemical fertilizer demand. Sustainability 2019, 11, 3211. [CrossRef]

112. Mangialardo, A.; Micelli, E. Rethinking the Construction Industry under the Circular Economy: Principles and Case Studies; Bisello, A., Vettorato, D., Laconte, P., Costa, S., Eds.; Smart and Sustainable Planning for Cities and Regions. SSPCR 2017. Green Energy and Technology; Springer: Cham, Switzerland, 2018. [CrossRef]

113. Barjoveanu, G.; Pătrăuțanu, O.; Teodosiu, C.; Volf, I. Life cycle assessment of polyphenols extraction processes from waste biomass. Sci. Rep. 2020, 10. [CrossRef] [PubMed]

114. Nunes, L.J.R.; Loureiro, L.M.E.F.; Sá, L.C.R.; Silva, H.F.C. Evaluation of the potential for energy recovery from olive oil industry waste: Thermochemical conversion technologies as fuel improvement methods. Fuel 2020, 279. [CrossRef]

115. Montoro, S.B.; Lucas, J., Jr.; Santos, D.F.L.; Costa, M.S.S.M. Anaerobic co-digestion of sweet potato and dairy cattle manure: A technical and economic evaluation for energy and biofertilizer production. J. Clean. Prod. 2019, 226, 1082-1091. [CrossRef]

116. Ghanim, B.; O’Dwyer, T.F.; Leahy, J.J.; Willquist, K.; Courtney, R.; Pembroke, J.T.; Murnane, J.G. Application of KOH modified seaweed hydrochar as a biosorbent of vanadium from aqueous solution: Characterisations, mechanisms and regeneration capacity. J. Environ. Chem. Eng. 2020, 8. [CrossRef]

117. Kurańska, M.; Beneš, H.; Prociak, A.; Trhlíková, O.; Walterová, Z.; Stochlińska, W. Investigation of epoxidation of used cooking oils with homogeneous and heterogeneous catalysts. J. Clean. Prod. 2019, 236. [CrossRef] 
118. López-Cano, I.; Cayuela, M.L.; Sánchez-García, M.; Sánchez-Monedero, M.A. Suitability of different agricultural and urban organic wastes as feedstocks for the production of biochar-part 2: Agronomical evaluation as soil amendment. Sustainability 2018, 10, 2077. [CrossRef]

119. Mateus, D.M.R.; Pinho, H.J.O. Screening of solid waste as filler material for constructed wetlands. In Proceedings of the IOP Conference Series: Earth and Environmental Science, Banda Aceh, Indonesia, 26-27 September 2018; p. 182. [CrossRef]

120. Mumbach, G.D.; Bolzan, A.; Machado, R.A.F. A closed-loop process design for recycling expanded polystyrene waste by dissolution and polymerization. Polymer 2020, 209. [CrossRef]

121. Silva, T.H.; Mesquita-Guimarães, J.; Henriques, B.; Silva, F.S.; Fredel, M.C. The potential use of oyster shell waste in new value-added by-product. Resources 2019, 8, 13. [CrossRef]

122. Breure, A.M.; Lijzen, J.P.A.; Maring, L. Soil and land management in a circular economy. Sci. Total Environ. 2018, 624, 1025-1030. [CrossRef] [PubMed]

123. Cucchiella, F.; D'Adamo, I.; Gastaldi, M. Sustainable italian cities: The added value of biomethane from organic waste. Appl. Sci. 2019, 9, 2221. [CrossRef]

124. Masullo, A. Organic wastes management in a circular economy approach: Rebuilding the link between urban and rural areas. Ecol. Eng. 2017, 101, 84-90. [CrossRef]

125. Rada, E.C.; Ragazzi, M.; Torretta, V.; Castagna, G.; Adami, L.; Cioca, L.I. Circular economy and waste to energy. In Proceedings of the AIP Conference Proceedings, Beirut, Lebanon, 1-3 February 2018; Volume 1968. [CrossRef]

126. Ragazzi, M.; Fedrizzi, S.; Rada, E.C.; Ionescu, G.; Ciudin, R.; Cioca, L.I. Experiencing urban mining in an italian municipality towards a circular economy vision. Paper presented at the Energy Procedia 2017, 119, 192-200. [CrossRef]

127. De Boer, M.A.; Romeo-Hall, A.G.; Rooimans, T.M.; Slootweg, J.C. An assessment of the drivers and barriers for the deployment of urban phosphorus recovery technologies: A case study of the Netherlands. Sustainability 2018, 10, 1790. [CrossRef]

128. Jedelhauser, M.; Mehr, J.; Binder, C.R. Transition of the swiss phosphorus system towards a circular economy-part 2: Sociotechnical scenarios. Sustainability 2018, 10, 1980. [CrossRef]

129. Moya, B.; Sakrabani, R.; Parker, A. Realizing the circular economy for sanitation: Assessing enabling conditions and barriers to the commercialization of human excreta derived fertilizer in Haiti and Kenya. Sustainability 2019, 11, 3154. [CrossRef]

130. Rufí-Salís, M.; Brunnhofer, N.; Petit-Boix, A.; Gabarrell, X.; Guisasola, A.; Villalba, G. Can wastewater feed cities? determining the feasibility and environmental burdens of struvite recovery and reuse for urban regions. Sci. Total Environ. 2020, 737. [CrossRef]

131. Liu, X.; Xiao, X. The optimization of cyclic links of live pig-industry chain based on circular economics. Sustainability 2016, 8, 26. [CrossRef]

132. Sayadi-Gmada, S.; Rodríguez-Pleguezuelo, C.R.; Rojas-Serrano, F.; Parra-López, C.; Parra-Gómez, S.; García-García, M.C.; García-Collado, R.; Lorbach-Kelle, M.B.; Manrique-Gordillo, T. Inorganic waste management in greenhouse agriculture in almeria (SE Spain): Towards a circular system in intensive horticultural production. Sustainability 2019, 11, 3782. [CrossRef]

133. Seghetta, M.; Hou, X.; Bastianoni, S.; Bjerre, A.; Thomsen, M. Life cycle assessment of macroalgal biorefinery for the production of ethanol, proteins and fertilizers-A step towards a regenerative bioeconomy. J. Clean. Prod. 2016, 137, 1158-1169. [CrossRef]

134. Seghetta, M.; Tørring, D.; Bruhn, A.; Thomsen, M. Bioextraction potential of seaweed in Denmark-an instrument for circular nutrient management. Sci. Total Environ. 2016, 563-564, 513-529. [CrossRef] [PubMed]

135. Sosa-Hernández, J.E.; Romero-Castillo, K.D.; Parra-Arroyo, L.; Aguilar-Aguila-Isaías, M.A.; García-Reyes, I.E.; Ahmed, I.; Parra-Saldivar, R.; Bilal, M.; Iqbal, H.M.N. Mexican microalgae biodiversity and state-of-the-art extraction strategies to meet sustainable circular economy challenges: High-value compounds and their applied perspectives. Mar. Drugs 2019, 17, 174. [CrossRef] [PubMed]

136. Torres, M.D.; Stefan Kraan, S.; Dominiguez, H. Seaweed biorefinery. Rev. Environ. Sci. Biotechnol. 2019, 18, 335-388. [CrossRef]

137. Vaneeckhaute, C.; Belia, E.; Meers, E.; Tack, F.M.G.; Vanrolleghem, P.A. Nutrient recovery from digested waste: Towards a generic roadmap for setting up an optimal treatment train. Waste Manag. 2018, 78, 385-392. [CrossRef]

138. Jin, R.; Yuan, H.; Chen, Q. Science mapping approach to assisting the review of construction and demolition waste management research published between 2009 and 2018. Resour. Conserv. Recycl. 2019, 140, 175-188. [CrossRef]

139. Nuñez-Cacho, P.; Górecki, J.; Molina-Moreno, V.; Corpas-Iglesias, F.A. What gets measured, gets done: Development of a circular economy measurement scale for building industry. Sustainability 2018, 10, 2340. [CrossRef]

140. Ghisellini, P.; Ji, X.; Liu, G.; Ulgiati, S. Evaluating the transition towards cleaner production in the construction and demolition sector of China: A review. J. Clean. Prod. 2018, 195, 418-434. [CrossRef]

141. Maina, S.; Kachrimanidou, V.; Koutinas, A. A roadmap towards a circular and sustainable bioeconomy through waste valorization. Curr. Opin. Green Sust. Chem. 2017, 8, 18-23. [CrossRef]

142. Rada, E.C.; Costa, L.; Pradella, C.; Adami, L.; Schiavon, M.; Magaril, E.; Torretta, V. Unconventional small-scale biogas production with reduced local impact. WIT Trans. Ecol. Environ. 2019, 4, 98-208. [CrossRef]

143. Ghisellini, P.; Ripa, M.; Ulgiati, S. Exploring environmental and economic costs and benefits of a circular economy approach to the construction and demolition sector. A literature review. J. Clean. Prod. 2018, 178, 618-643. [CrossRef]

144. Ghaffar, S.H.; Burman, M.; Braimah, N. Pathways to circular construction: An integrated management of construction and demolition waste for resource recovery. J. Clean. Prod. 2020, 244. [CrossRef] 